\title{
Od groźnych po zagrożone Alpy — procesy zawłaszczania i tożsamość alpejskich obrońców środowiska w Tyrolu
}

\author{
https://doi.org/10.19195/2084-4107.14.11
}

\section{Wprowadzenie}

„Pragniemy zachować i zachowamy tę przestrzeń alpejską jako przestrzeń życiową i gospodarczą, jako nasze dziedzictwo naturalne i kulturowe"l — deklarował tyrolski aktywista Fritz Gurgiser, przewodniczący Transitforum Austria-Tirol, zabierając głos na międzynarodowej konferencji w sprawie tranzytu przez Alpy w lutym 1997 roku. W dalszej części wystąpienia wskazał na, jego zdaniem konieczną, ochronę coraz bardziej zagrożonych współczesnymi problemami środowiskowymi Alp i zachowanie ich dla mieszkańców. Hałas, zanieczyszczenie powietrza, umieranie lasów i problemy z warstwą ozonową z każdą chwilą coraz mocniej zagrażają wrażliwej ekologicznie przestrzeni alpejskiej. Wprawdzie problemy związane ze zniszczeniem środowiska nie tworzyły kwestii specyficznie alpejskiej, lecz ze względu na zależności geograficzne i topograficzne ich skutki potęgowały się i były widoczne w szczególnie wyraźny sposób właśnie tutaj. $\mathrm{Z}$ tym istotnie narastającym obciążeniem po stronie przyrody korespondowała niezwykle intensywna dyskusja po stronie społecznej. Różnorodne, po części sprzeczne interesy natury ekonomicznej, ekologicznej i politycznej związane z wykorzystaniem przestrzeni alpejskiej starły się tym mocniej, że przestrzeń ta jest ograniczona. W zależności od kontekstu Alpy określano jako przestrzeń życiową, kulturową lub gospodarczą, jako ogród na dachu i wodny zamek Europy, jako idyllę wakacyjną lub arenę sportową. Szczególnej krytyce obrońców środowiska podlegały przy tym pozaalpejskie zakusy, a przede wszystkim zakusy Unii Europejskiej w obszarze turystyki, energii i transportu ${ }^{2}$. W pewnej austriackiej audycji radiowej z 1983 roku można usłyszeć, że Alpy stoją tuż przed agonią i nie potrwa długo, aż dojdzie do zawału tego skomplikowanego i bardzo podatnego na zaburzenia systemu naturalnego. Przyczyn łatwo było dociec: niepohamowana rozbudowa infrastruktury turystycznej i dróg, a także rozbudowa źródeł energii wodnej doprowadziły do poważnych zmian struktury gospodarczej w Alpach, a przez to także do transformacji naturalnego krajobrazu ${ }^{3}$.

Alpy tworzyły naturalną przeszkodę przede wszystkim dla transportu. Góry tworzyły naturalną barierę, możliwą do pokonania tylko w miejscach kilku przepraw mających duże znaczenie i koncentrujących na sobie ruch. Przełęcz Brenner między Tyrolem a Tyrolem Południowym do dziś jest najważniejszą i najbardziej

${ }^{1}$ Mit der Natur rechnen. Międzynarodowa Konferencja dotycząca tranzytu przez Alpy, 2122.02.1997. Tom pokonferencyjny, red. Transitform Austria Tirol, [b.m.d.], s. 4.

2 P. Glauser, D. Siegrist, Schauplatz Alpen, Gratwanderung in eine europäische Zukunft, Zürich 1997, s. 12; L. Lukschanderl, Rettet die Alpen. Europas Dachgarten in Bedrängnis, Wien 1983.

3 „Von Tag zu Tag”: Rettet die Alpen”, audycja radiowa Ö1, 31.10.1983.

Góry — Literatura - Kultura 14, 2020

(C) for this edition by CNS 
uczęszczaną przeprawą przez Alpy. Nie powinno więc dziwić, że ochronę środowiska w austriackim kraju związkowym Tyrol od lat siedemdziesiątych XX wieku zdominował jeden temat: ruch tranzy towy samochodów ciężarowych przez Alpy. Wraz z narastającym ruchem tranzytowym w Tyrolu Północnym i Południowym wzdłuż autostrady w dolinie rzeki Inn i autostrady przez przełęcz Brenner powstawały inicjatywy obywatelskie żądające wraz ze znanymi organizacjami związanymi z ochroną środowiska, a także ze Związkiem Alpejskim ograniczenia ruchu tranzytowego ${ }^{4}$. Podczas gdy jeszcze w latach sześćdziesiątych transport uchodził za ważny czynnik rozwoju gospodarczego, z perspektywy mieszkańców stał się z czasem niszczycielem przestrzeni życiowej, jaką są Alpy. Tak więc, jak twierdzi Werner Bätzing, nieprzypadkowo temat ruchu tranzytowego należy od ponad czterdziestu lat do najbardziej dyskutowanych kwestii alpejskich ${ }^{5}$. Zarówno w tematyce protestów, jak i w sposobie działania alpejskich obrońców środowiska można wyraźnie dostrzec wzajemne oddziaływanie fizycznej i wyimaginowanej przestrzeni alpejskiej będącej przedmiotem dyskusji.

Jeśli uwzględnimy, że współpraca alpejskich obrońców środowiska po północnej i południowej stronie przełęczy Brenner istniała mimo granic państwowych, a także w kontekście niezwykle różnorodnego pod względem społecznym i politycznym ruchu oporu w Tyrolu Północnym, rodzi się pytanie: w jakim stopniu Alpy generowały specyficzne formy identyfikacji wśród uczestników tych wydarzeń? W niniejszym przyczynku prezentowana jest teza, że dla alpejskich obrońców środowiska Alpy były przestrzenią zarówno dyskursywną, jak $\mathrm{i}$ istniejącą fizycznie, która pomagała $\mathrm{w}$ identyfikacji oraz umożliwiała działania ponad granicami narodowymi i społeczno-politycznymi. W tekście, stosując podejście dyskursywno-analityczne, zbadano Alpy w napięciu między interesami poza- i wewnątrzalpejskimi, ale i ich zawłaszczanie przez obrońców środowiska na przykładzie tyrolskiego ruchu przeciwtranzytowego ${ }^{6}$.

\section{Tło: ruch przeciw tranzytowi w Tyrolu}

Historia oporu przeciw ruchowi tranzytowemu w Tyrolu to przede wszystkim historia protestu wyrażającego się w licznych akcjach organizowanych od

${ }^{4}$ M. Pernold, Die Brennerautobahn als Infrastruktur für Verkehr und Transit: Zur Entgrenzung geografischer Verkehrsräume im Zeitraum ihrer Realisierung, „Geschichte und Region, Verkehr und Infrastruktur" 25, 2016, s. 64-81, tutaj s. 79; Ch. Stadel, The Brenner Freeway (AustriaItaly): Mountain Highway of Controversy, „Mountain Research and Development” 13 (1), 1993, s. 1-17; H. Sickinger, R. Hussl, Transit-Saga. Bürgerwiderstand am „Auspuff Europas“, ThaurWien-München 1993.

5 W. Bätzing, Die Alpen. Geschichte und Zukunft einer europäischen Kulturlandschaft, München 2015, s. 139.

${ }^{6}$ Jako źródła służą przede wszystkim publikacje tyrolskich inicjatyw obywatelskich zarchiwizowane w Bibliotece Ferdinandeum w Innsbrucku, jak też sprawozdania z dzienników i tygodników z Tyrolu, Tyrolu Południowego i całej Austrii. W celu śledzenia dyskusji sięgnięto również do nagrań telewizyjnych i radiowych dostępnych w Mediatece Austriackiej w Wiedniu.

Góry - Literatura - Kultura 14, 2020

(C) for this edition by CNS 
początku lat osiemdziesiątych XX wieku do połowy pierwszej dekady XXI wieku. Jego korzenie tkwią w okresie powojennym, kiedy to w Tyrolu w sposób tak konsekwentny jak w żadnym innym regionie alpejskim doprowadzono do rozbudowy sieci dróg prowadzących przez Alpy. Kiedy to w 1975 roku autostrada między Kufsteinem a przełęczą Brenner była wreszcie całkowicie przejezdna, połączyła ona jako trasa tranzytowa najważniejsze gospodarcze centra europejskiej Północy z takimiż centrami Południa. Jednak od lat osiemdziesiątych powojenne hasło tyrolskiego rządu „Ruch to życie” dotykała coraz większa presja7. Mimo pojedynczych protestów w latach siedemdziesiątych działania przeciwko tranzytowi nie były aż do lat osiemdziesiątych tematem publicznym, medialnym. Jednak dyskusja o odporności Alp i ich mieszkańców na skutki ruchu tranzytowego, takie jak hałas czy szkodliwe substancje, rosła i stopniowo zataczała coraz szersze kręgi. Naukowe badania spowodowały, że można było zmierzyć obciążenie ruchem drogowym, hałasem i spalinami, a tym samym zobiektywizowały wcześniejsze subiektywne odczucia mieszkańców: wzdłuż autostrady przez dolinę Inn i na przełęczy Brenner regularnie przekraczane były wartości graniczne, w mleku wykrywano ołów, a w glebie metale ciężkie ${ }^{8}$. Ponadto lekarze potwierdzali coraz więcej przypadków chorób płuc i dróg oddechowych występujących u osób mieszkających wzdłuż drogi tranzytowej, a także diagnozowali ponadprzeciętną liczbę chorób wynikających z narażenia na hałas. Na tle tego zewnętrznego, wywołanego przez ludzi, naporu użytkowego na Alpy wraz z jego siejącymi spustoszenie skutkami dla ludzi i przyrody łatwo wytłumaczyć nadejście od lat osiemdziesiątych szczytowego momentu protestów, który utrzymywał się do połowy lat dziewięćdziesiątych. Dlatego również inicjatywy obywatelskie postawiły sobie za cel przeforsowanie podstawowego prawa do zachowania indywidualnego zdrowia ${ }^{9}$.

Przeciwnicy tranzytu przez Alpy za punkt główny działań politycznych obrali podstawową zasadę dotyczącą człowieka i natury. Celem protestów stała się wiązka różnorakich środków mających ograniczyć ruch tranzytowy. W ten sposób można było nie tylko chronić alpejskie przestrzenie życiowe i gospodarcze, lecz także same Alpy mogły stać się stabilnym ekosystemem i zachować się jako środkowoeuropejski krajobraz wypoczynkowy. Oprócz tego protestujący dążyli do wspierania struktur gospodarczych obejmujących małe obszary, co

${ }^{7}$ M. Achrainer, N. Hofinger, Politik nach, ,Tiroler Art - ein Dreiklang aus Fleiß, Tüchtigkeit und Zukunftsglaube". Anmerkungen, Anekdoten und Analysen zum politischen System Tirols 19451999, [w:] Tirol. „Land im Gebirge”: Zwischen Tradition und Moderne, red. M. Gehler, Wien-Köln-Weimar 1999, s. 27-136, tutaj s. 94.

8 W. Tipotsch, Verkehr als krankmachender Faktor, „Lebensraum Tirol” 2, 1987, s. 9; Zustand der heimischen Wälder, „Ö1 Mittagsjournal” 11.08.1989; J. Gaulke, Blei in der Bergluft. Österreich wehrt sich gegen den Lastwagen-Transit, „Die Zeit” 9.06.1989, s. 25-27, tutaj s. 27.

95 nach 12. Stopp Transit. Für Gesundheit und Arbeitsplätze, „Tatort Brenner” 4, Transitforum Austria-Tirol, Innsbruck 2002, s. 16-18; O. Kolp, ,, Die gescheiterte Transitpolitik? “ Der alpenquerende Straßengüterverkehr anhand des Fallbeispiels Tirol - Die Verkehrspolitik Österreichs, der EU und der Schweiz, Innsbruck 2015, s. 67.

Góry - Literatura - Kultura 14, 2020

(C) for this edition by CNS 
miało zostać osiągnięte poprzez podrożenie i kontyngentowanie transportu przez Alpy. Żądania przeciwników ruchu tranzytowego: zakaz poruszania się samochodów ciężarowych powyżej 7,5 tony w nocy, w weekendy oraz dni świąteczne, ograniczenie wagi pojazdów do 28 ton, zakaz transportu określonych towarów na drogach oraz konsekwentna rozbudowa infrastruktury kolejowej w celu przeniesienia transportu na szyny ${ }^{10}$.

\section{Dyskusja o odporności Alp}

Alpy były i są przestrzenią o specyficznych uwarunkowaniach geologicznych, klimatycznych i kulturowych. Tworzą one największe i najwyższe pasmo górskie Europy, lecz do dziś nie udaje się jednoznacznie zdefiniować przestrzeni alpejskiej — ani pod względem geograficznym, ani politycznym ${ }^{11}$. Wskazuje się w celu takiego określenia raczej różne aspekty, co też przynosi różne rezultaty ${ }^{12}$. Nie można więc mówić o Alpach jako takich, mamy tu do czynienia ze zbyt różnorodnymi i nieprzeniknionymi relacjami, jak konstatuje Ingwald Gschwandtl, były prezes austriackiego oddziału Międzynarodowej Komisji Ochrony Alp $(\text { CIPRA })^{13}$. Dla alpejskich obrońców środowiska taki brak konkretnej definicji oznaczał wniesienie własnych sposobów rozumienia i celów, aby ze swej strony określić przestrzeń alpejską. Dawało to im szansę pojmowania Alp jako przestrzeni dyskursywnej, którą można zapełnić znaczeniami, co tworzyło wachlarz możliwości mieniących się odcieniami od jednoznaczności po niejasność. Zasadniczo alpejscy obrońcy środowiska odnosili się w swoich motywowanych politycznie manifestach i deklaracjach do konwencji alpejskiej podpisanej w roku 1991 przez ministrów środowiska krajów alpejskich ${ }^{14}$.

Niezależnie od różnych definicji przestrzeni alpejskiej w latach siedemdziesiątych XX wieku pod wpływem wzrastającej w przestrzeni publicznej świado-

10 A. Weissen, Verkehr, [w:] Naturfreunde International, Grünbuch Alpen. Die Alpen - Prüfstein Europas, Wien 1996, s. 17-19; Alpenschutz-Transiterklärung, http://www.transitforum.at/pdf/ AlpenschutzTransiterklaerung.pdf (dostęp: 10.04.2020).

11 W. Bätzing, op. cit., s. 21.

12 M. Stremlow, Die Alpen aus der Untersicht. Von der Verheissung der nahen Fremde zur Sportarena. Kontinuität und Wandel von Alpenbildern seit 1700, Bern-Stuttgart-Wien 1998, s. 12; J. Mathieu, Die Alpen. Raum. Kultur. Geschichte, Stuttgart 2015, s. 25.

${ }^{13}$ I. Gschwandtl, Die Alpen - alte Mythen oder neue Visionen?, [w:] Mythos Alpen. CIPRA Jahreskonferenz, 10.-12. Oktober 1996, Igls, red. Ch. Wildburger, Wien 1996, s. 13-14, tutaj s. 14.

14 Konwencja alpejska jest międzynarodową umową państwową wszystkich krajów mających udział w Alpach oraz Unii Europejskiej, mającą na celu ochronę przestrzeni Alp i nakierowaną na zrównoważony rozwój tego obszaru. E. Galle, Das Übereinkommen zum Schutz der Alpen (Alpenkonvention) und seine Protokolle, Berlin 2002; K. Conradin, Ch. Baumgartner, Die Alpenkonvention und ihre Protokolle. Ein Rahmen für eine nachhaltige Entwicklung in den Alpen, [w:] Alpenreisen. Erlebnis, Raumtransformationen, Imagination, red. K. Luger, F. Rest, Innsbruck 2017, s. 267-282; więcej zob. J. Mathieu, Der Alpenraum, Europäische Geschichte Online (EGO), Mainz $2013(15.05 .2018)$.

Góry - Literatura - Kultura 14, 2020

(C) for this edition by CNS 
mości ekologicznej upowszechniała się dyskusja o obciążeniu Alp współczesnymi problemami związanymi ze środowiskiem oraz o możliwym ich oddziaływaniu na wrażliwy ekosystem alpejski ${ }^{15}$. W owym czasie potrzeba ochrony środowiska alpejskiego nie była w żadnym razie nowym tematem: już na przełomie wieków powstał ruch wypowiadający się przeciwko zmasowanej ingerencji w Alpy i angażujący się w ich ochronę $e^{16}$. W latach siedemdziesiątych debata o przeciążeniu środowiska alpejskiego nabrała nowej dynamiki, wspierana przez liczne inicjatywy obywatelskie, towarzystwa alpejskie i towarzystwa ochrony środowiska, a także przez reprezentujące różne interesy polityczne siły. Na terenie całych Alp pojawiła się fala nowych inicjatyw protestujących przeciw projektom związanym z powstawaniem takiej infrastruktury, jak zbiorniki retencyjne tworzone w celu pozyskiwania energii, udostępnianiu nowych obszarów dla turystyki, przede wszystkim sportów zimowych, a także przeciwko budowie nowych dróg jako tras tranzytowych $^{17}$. Żądania radykalnej zmiany sposobu myślenia w celu ochrony Alp, a także własnej ,polityki alpejskiej” stawały się coraz częściej tematem debaty medialnej.

Boom publikacji noszących takie tytuły jak Sind die Alpen noch zu retten? Die Zerstörung eines Lebensraumes (Czy Alpy da się jeszcze uratować? Zniszczenie przestrzeni życiowej) $)^{18}$, Die Alpen — schleichende Zerstörung eines Mythos (Alpy — skradające się zniszczenie mitu) ${ }^{19}$ czy Rettet die Alpen. Europas Dachgarten in Bedrängnis (Ratujcie Alpy. Ogród na dachu w niebezpieczeństwie) ${ }^{20}$, kierujących uwagę społeczną na Alpy, objawił się zwłaszcza w latach osiemdziesiątych. Szczególne znaczenie miała publikacja Die Alpen. Geschichte und Zukunft einer europäischen Kulturlandschaft (Alpy. Historia i przyszłość europejskiego krajobrazu kulturowego) geografa Wernera Bätzinga, która ukazała się po raz pierwszy w roku 1984 i potem wielokrotnie była wznawiana. Autor podkreślał, że planowane krótkofalowo nowoczesne sposoby wykorzystania Alp niszczą ich biologiczną różnorodność i ekologiczną stabilność i domagał się zdecentralizowanego gospodarowania oraz zrównoważonej odpowiedzialności za środowisko. Tylko w ten sposób jego zdaniem Alpy nie przestaną być ludzką przestrzenią życia i gospodarki ani nie znikną z powierzchni świata jako nienaruszony system ekologiczny ${ }^{21}$.

Dyskusja dotycząca obciążenia Alp nie przebiegała tylko w kręgu obrońców środowiska, lecz znalazła również wyraz w polityce. Przyjął się pogląd, że Alpy stawiają przed wszystkimi swoimi mieszkańcami podobne wyzwania. Naturalne

15 P. Kupper et al., Die Grenzen des Wachstums (1972), [w:] Geschichte des politischen Denkens. Das 20. Jahrhundert, red. M. Brocker, Berlin 2018, s. 548-561.

16 K. Stankiewitz, Wie der Zirkus in die Berge kam. Die Alpen zwischen Idylle und Rummelplatz, München 2012, s. 225.

17 R. Aschwanden, ,Für eine Opposition in den Alpen “. Transnationale Dimension des Widerstands gegen den Transitverkehr durch die Alpen in den 1990er Jahren, „Histoire des Alpes Storia delle Alpi - Geschichte der Alpen" 23, 2018, s. 259-273, tutaj s. 259.

18 M. Heinrich, Sind die Alpen noch zu retten? Die Zerstörung eines Lebensraumes, München 1988.

19 A. Schmidt, Die Alpen — schleichende Zerstörung eines Mythos, Zürich 1990.

${ }^{20}$ L. Lukschanderl, op. cit.

21 W. Bätzing, op. cit., s. 9.

Góry - Literatura - Kultura 14, 2020

(C) for this edition by CNS 
niebezpieczeństwa, jak też procesy społeczno-ekonomiczne zdawały się porównywalne we wszystkich górskich obszarach Alp. Jako przykłady można wymienić założenie Arge Alp w 1972 lub grupy Alpenraum w Komisji Regionalnej Unii Europejskiej w 2001 roku $^{22}$. Symbolicznym kamieniem milowym na płaszczyźnie politycznej było dla alpejskich obrońców środowiska wymienione już porozumienie o ochronie Alp, w skrócie Konwencja ochrony Alp z roku 1991. Chodzi tu o odnoszącą się do prawa międzynarodowego umowę dotyczącą ochrony i zrównoważonego rozwoju Alp mającą na celu wypracowanie strategii ochrony przyrody i krajobrazu ponad granicami państwowymi, a także zagwarantowanie wymiany informacji i doświadczeń pomiędzy krajami ${ }^{23}$. Alpy stały się widoczne nie tylko na płaszczyźnie europejskiej dzięki Konwencji ochrony Alp, lecz także globalnie dzięki rozdziałowi Agendy 21 Konferencji Środowiska Narodów Zjednoczonych w Rio w 1992 roku, w którym zostały uznane jak inne regiony górskie po raz pierwszy za godne objęcia ochroną obszary przyrodnicze. Rozdział 13, o którym mowa, dotyczący „Górskiej gospodarki wrażliwych systemów ekologicznych: Zrównoważonego rozwoju terenów górskich”, zapisał na trwałe znaczenie regionów górskich jako zbiornika zasobów oraz zamanifestował ich chroniczne zagrożenie ${ }^{24}$.

To w kontekście tych dyskusji wokół odporności Alp, które szczególnie mocno oddziaływały na opinię społeczną w latach siedemdziesiątych i osiemdziesiątych, należy umiejscowić działania alpejskich obrońców środowiska w Tyrolu i innych regionach Alp. Tworzyli oni ramy, a w ostatecznej konsekwencji także przyczynę protestów przeciwko obciążeniom środowiska alpejskiego i jego mieszkańców spowodowanym ruchem tranzytowym.

\section{Procesy zawłaszczania przez alpejskich obrońców środowiska}

Alpejscy obrońcy środowiska w Tyrolu podkreślali centralne położenie Alp w Europie i przypisywali im funkcję strefy kontaktu i spotkań położonej w miejscu, w którym przecinają się różne międzynarodowe powiązania. Szczególnie jawnie widać to na przykładzie przecinającego Alpy ruchu tranzytowego manifestującego ścisłe powiązanie terenów alpejskich ze strumieniem dóbr transportowanych między europejskimi centrami gospodarczymi. Rozpowszechniona

22 Nachbarn im Herzen Europas. 20 Jahre Arbeitsgemeinschaft Alpenländer, red. Arbeitsgemeinschaft Alpenländer, München 1992; W. Bätzing, Die aktuellen Probleme des Alpenraums und die Frage einer staatenübergreifenden „Alpen-Konvention”, [w:] Schützt die Alpen! Aufgabe der europäischen Umweltpolitik, red. K. Huttner, W. Danz, Stuttgart-München 1991, s. 29-43.

23 M. Stremlow, op. cit., s. 220.

24 „Managing Fragile Ecosystems: Sustainable Mountain Development”. United Nations: Agenda 21. United Nations Conference on Environment \& Development. Rio de Janerio, Brazil, 3 to 14 June 1992, Rio de Janeiro; por. J. Mathieu, The Third Dimension: A comparative history of mountains in the modern era, Knapwell 2011. 
przed II wojną światową interpretacja Alp jako przeszkody uważana była przez aktywistów za od dawna nieaktualną ze względu na intensywne udostępnienie infrastrukturalne: drogi prowadzące przez Alpy oraz gęsta sieć dróg w najodleglejszych dolinach zapewnia od czasów powojennych wygodne połączenie z Alpami. Także rozbudowa infrastruktury turystycznej, takiej jak stoki narciarskie i drogi podejściowe, spowodowała, że Alpy stawały się dla coraz większej części Europy ulubioną idyllą wakacyjną i miejscem uprawiania sportów zimowych ${ }^{25}$. Dzięki infrastrukturze Alpy z odległych przerodziły się w bliskie.

Ten boom związany z uprzystępnianiem Alp wywoływał jednakowoż krytykę i opór. Na pierwszy plan wysuwały się kwestie zrównoważonych sposobów ich wykorzystania, a w mediach coraz częściej prowadzono dyskusje nakierowane na problemy środowiska:

Alpy jako szczególnie wrażliwy pod względem ekologicznym obszar można ukazać jako system wczesnego ostrzegania dla Europy. A to dlatego, że ze względu na specyficzne uwarunkowania przyrodnicze alpejskie ekosystemy są szczególnie narażone na skutki niezbyt zrównoważonego sposobu gospodarowania europejskiego społeczeństwa usługowego ${ }^{26}$

- podsumowywali, prezentowane również przez austriackich i włoskich aktywistów, przekonania Peter Glauser i Dominik Siegrist, sami aktywnie działający na rzecz ochrony środowiska w Szwajcarii. Przy tym Alpy jako triada przestrzeni życiowej, kulturowej i gospodarczej tworzyła dla przeciwników ruchu tranzytowego punkt centralny — te funkcje należało chronić i bronić. Obrońcy środowiska postrzegali siebie jako adwokatów regionu alpejskiego, ponieważ reprezentowali pogląd, że jego potrzeby mogą zostać odpowiednio uwzględnione tylko przez ich wyartykułowanie od wewnątrz ${ }^{27}$.

Dla przestrzeni alpejskiej w czasie powojennym szczególne znaczenie miały dwie linie rozwoju, jak wynika z opracowania Jona Mathieu: z jednej strony integracja europejska, która rozpoczęła się w latach pięćdziesiątych, z drugiej zaś,

25 A. Bonoldi, H. Obermair, Editorial, „Geschichte und Region, Verkehr und Infrastruktur” 25, 2016, nr 2, s. 5-17, s. 7; w historycznej perspektywie zob. R. Groß, Die Beschleunigung der Berge. Eine Umweltgeschichte des Wintertourismus in Vorarlberg/Österreich, 1920-2010, Köln 2019.

26 P. Glauser, D. Siegrist, op. cit., s. 13.

27 Transitforum Austria-Tirol oświadczyło, że obywatele powinni sami w większym stopniu brać odpowiedzialność, tak aby móc dzieciom przekazać nienaruszoną przestrzeń życiową i gospodarczą w Alpach. Ponadto byli przekonani, że ,angażowanie się w dyskusję polityczną [to] obowiązek każdej obywatelki i każdego obywatela państwa [...]. Jeśli obywatele trzymają usta zamknięte, to nie mogą niczego oczekiwać od polityki — »Milczenie oznacza zgodę«. Każde dobre czy złe działanie polityczne wypływa $\mathrm{z}$ form nacisku. Jeśli nacisk ten przychodzi ze strony zwolenników ruchu tranzytowego, to odpowiedzią na to musi być nacisk ze strony obywateli”, Am Beispiel Alpentransit: Gnadenlos verraten und Verkauft. Über Demokratie und Widerstand, über Wahlversprechen und Wahlbetrug, „Tatort Brenner” 1, Transitforum Austria-Tirol, Innsbruck 1999, s. 4. Zob. Helfen wir den Alpen. Wie sich die Alpenvereine aus Deutschland, Österreich und Südtirol den Schutz der Alpen vorstellen - und was alle dafür tun können, Prospektheft, Bozen-München-Innsbruck 1995.

Góry - Literatura - Kultura 14, 2020

(C) for this edition by CNS 
po roku 1970, coraz większa świadomość ekologiczna ${ }^{28}$. Procesy zawłaszczania przestrzeni alpejskiej przez aktywistów ruchu przeciw tranzytowi w Tyrolu można zrozumieć dopiero na tle tych dwóch czynników, jako że są one dyskusją splecione $\mathrm{z}$ obydwoma. Dlatego postaramy się teraz przedstawić powiązania między oboma wątkami dyskursu.

Przez integrację europejską Alpy z peryferii uzyskały pozycję centralną, można powiedzieć, że stały się ,,sercem Europy”, co spowodowało, że zostały dostrzeżone na płaszczyźnie politycznej, a zarazem zyskały znaczenie społeczne ${ }^{29}$. W konsekwencji ta autorefleksja w odniesieniu do przestrzeni życiowej doprowadziła do powstania zalążków „świadomości alpejskiej” i stworzyła rozległą podstawę do demokratycznych rozstrzygnięć w kwestiach związanych z dobrami i roszczeniami mających się dokonywać w przyszłości ${ }^{30}$. Powstała upolityczniona przestrzeń alpejska służąca alpejskim obrońcom środowiska jako ramy działania. W tych ramach zaklinali ,alpejską odporność”31 i motywowali się wzajemnie do wzięcia swej przyszłości we własne ręce i angażowania się w sprawę zrównoważonego rozwoju w Alpach ${ }^{32}$. „Decyzja brzmi: Prawo do samostanowienia dla regionu Alp. Nie chcemy, aby w Brukseli, Wiedniu, Bonn czy gdziekolwiek indziej podejmowano decyzje ponad naszymi głowami"33. W publikacji Transitforum Austria-Tirol można przeczytać, że alpejscy obrońcy środowiska opowiadali się za zdecentralizowaną Europą regionów oraz za aktywnym współdziałaniem ludności zamieszkującej Alpy ${ }^{34}$.

$\mathrm{Na}$ losy przestrzeni alpejskiej od lat siedemdziesiątych coraz mocniejszy wpływ miały także dyskusje ekologiczne, co znalazło wyraz w powstawaniu towarzystw i inicjatyw obywatelskich angażujących się w ochronę środowiska alpejskiego. Przyniosło to nową retorykę: po części alarmujące wołanie o nowy stosunek do środowiska ukazało wyraźnie, że po latach niepohamowanego wzrostu zaczęły być zauważalne granice społecznej wydajności i wytrzymałości przyrody. „Można to spuentować tak, że nowe ruchy ekologiczne zajmowały się mniej zewnętrzną przyrodą, którą należy uchować, a bardziej zawinionymi przez samych siebie zmianami środowiska szkodzącymi ludziom"35, jak to ujmują Martin Schmid i Ortrun Veichtelbauer. Współczesne postrzeganie środowiska zdaje się uwidaczniać problemy, krytyczny stan środowiska traktowany jest

28 J. Mathieu, op. cit., s. 191.

29 R. Aschwanden, op. cit., s. 263.

30 J. Mathieu, op. cit., s. 215.

31 „Dolomiten” 10.06.1998, s. 3.

32 Es brannte wieder, „Naturschutzblatt: Mitteilungen zum Natur- und Umweltschutz in Südtirol" 17, 2001, nr 3, s. 14.

33 F. Gurgiser, Treuhänder und Erben unseres Lebensraumes, „Pro Vita Alpina” 1997, nr 43-44, s. $42-45$, tutaj s. 42.

${ }^{34}$ P. Glauser, D. Siegrist, op. cit., s. 24.

35 M. Schmid, O. Veichtelbauer, Vom Naturschutz zur Ökologiebewegung, Umweltgeschichte Österreichs in der Zweiten Republik, Innsbruck 2006, s. 12. 
jako destrukcyjna ludzka ingerencja w zależności ekologiczne ${ }^{36}$. W szeregi te wstąpili również przeciwnicy ruchu tranzytowego: problematykę związaną z ruchem tranzytowym postrzegali nie jako daną, lecz jako problem stworzony przez ludzi, który można rozwiązać przez bardziej wrażliwą ekologicznie politykę mobilnościową i gospodarczą ${ }^{37}$. Nie dążyli oni w żadnym razie do obwołania Alp jednym wspólnym obszarem chronionym, w którym zakazane byłyby wszelkie ludzkie aktywności. Gdyż mieszkańcy Alp nie chcieli sami siebie zdegradować do „obiektów lub strażników muzealnych” ${ }^{38}$. Celem obrońców środowiska było raczej tworzenie przykładu w kwestii zrównoważonego rozwoju Europy, dystansowali się oni w sposób świadomy od wyobrażenia o nienaruszonym świecie gór, uważając je za zbyt oderwane od rzeczywistości w czasach masowej turystyki, elektrowni wodnych i lawin ruchu tranzytowego ${ }^{39}$. Alpy widzieli raczej jako główny, usieciowiony region w Europie, wyraźnie odróżniający się od innych jej części z powodu specyficznych problemów przestrzennych i strukturalnych. $\mathrm{Na}$ przykładzie Alp i w Alpach dyskutowano o palących problemach środowiska, wskazujących na szczególną kruchość tego wrażliwego ekologicznie krajobrazu naturalnego i kulturowego.

\section{Identyfikacja i odgraniczenie}

Jak już wspomniano, w Tyrolu Północnym i Południowym powstała gęsta sieć organizacji ochrony środowiska, związków alpejskich, inicjatyw obywatelskich, gminnych i towarzystw angażujących się w ochronę alpejskiej przestrzeni życiowej. Niezależnie od różnic merytorycznych wszystkie te organizacje i miejscowe inicjatywy przeciwstawiały się pozaalpejskim roszczeniom w szczególności w dziedzinie ruchu tranzytowego ${ }^{40}$. Elementem łączącym na płaszczyźnie zarówno realnej politycznej, jak i symbolicznej były Alpy. Tworzyły wspólną przestrzeń działania oraz punkt odniesienia, z którymi aktywiści byli osobiście i emocjonalnie związani. Wedle Ulricha Leitnera można tu mówić o „tożsamości odnoszącej się do krajobrazu’41 . Krajobraz alpejski pełnił funkcję orientacyjną,

36 V. Winiwarter, M. Knoll, Umweltgeschichte. Eine Einführung, Köln-Weimar-Wien 2007, s. 271.

37 H. Sickinger, R. Hussl, op. cit.

38 L. Lukschanderl, op. cit., s. 17.

39 M. Stremlow, op. cit., s. 268; por. też K.W. Brand, Umweltbewegung; Die sozialen Bewegungen in Deutschland seit 1945. Ein Handbuch, red. R. Roth, D. Rucht, Frankfurt-New York 2008, s. 219-244.

40 Tak również Transitforum Austria-Tirol: Am Brenner für die Alpen, „Tatort Brenner” 2, Transitforum Austria-Tirol, Innsbruck 2000, s. 95.

${ }^{41}$ U. Leitner, Berg - Tirols poetischer Ort. Ein Modell zum Raum- und Landschaftsbezug der Identität, [w:] Berg \& Leute. Tirol als Landschaft und Identität, red. U. Leitner, Innsbruck 2014, s. 42-81, tutaj s. 49; por. także koncepcję Place Identity: P. Weichhart, Ch. Weiske, B. Werlen, Place Identity und Images. Das Beispiel Eisenhüttenstadt, Wien 2006.

Góry - Literatura - Kultura 14, 2020

(C) for this edition by CNS 
która budowała kolektywną tożsamość alpejskich obrońców środowiska. Właśnie w Tyrolu, ale też w Tyrolu Południowym czy w Szwajcarii Alpy ze swoimi charakterystycznymi formacjami górskimi stanowią obiekt krajobrazu, którego nie można pomylić z żadnym innym ${ }^{42}$.

Nawet jeśli Alpy jako środowisko naturalne nie są ,,aktorem wydarzeń w teoretycznym sensie dyscypliny historycznej"^33 , to nie można zanegować ich potężnej siły oddziaływania na alpejskich obrońców środowiska. Szczególna sytuacja związana z rozprzestrzenianiem się hałasu i szkodliwych substancji w wąskich dolinach odróżniała się znacząco od sytuacji na nizinach. Dlatego w oświadczeniu dotyczącym ochrony Alp w kontekście ruchu tranzytowego stwierdzono, że ograniczona przestrzeń życiowa Alp wyklucza jakąkolwiek formę nieograniczonej mobilności ${ }^{44}$. Także świadomość znaczenia, jakie ma nienaruszony las chroniący przed erozją, lawinami oraz osuwiskami, świadczy o przekazywanej tradycyjnie wiedzy i doświadczeniach życia codziennego w Alpach. Popyt na coraz większą przepustowość w ramach ruchu tranzytowego wpływał na transformację krajobrazu alpejskiego: budowa dróg, tuneli i ochronnych konstrukcji w sąsiedztwie miejsc zagrożonych erozją ukazywała dostrzegalne materialne oddziaływanie ruchu tranzytowego. W ten sposób lokalizacja obszaru działania alpejskich obrońców środowiska, sama przestrzeń alpejska oddziałuje na przedmiot protestu — ruch tranzytowy — a także na sposób działania i motywy zaangażowanych osób.

Koncepcja krajobrazu implikuje poddanie się również Alp specyficznej formie procesów transformacji i negocjacji. Krajobrazu nie należy rozumieć jako naturalnej stałej wartości, podlega on zarówno ze względu na wciąż zmieniające się wyobrażenia i konotacje, jak i ze względu na ludzkie ingerencje ustawicznym zmianom dyskursywnym i fizycznym ${ }^{45}$. Krajobraz jest więc konstruktem społecznym, który można zmieniać i kształtować, przez co odgrywa on główną rolę $\mathrm{w}$ procesach tożsamościowych i odrębnościowych ${ }^{46}$. Także szwajcarskie studia dotyczące krajobrazu alpejskiego wskazują na jego identyfikacyjny aspekt wywołujący uczucie przynależności ${ }^{47}$. W odniesieniu do zaangażowania alpejskich obrońców środowiska będących mieszkańcami Alp, a tym samym przeży-

42 U. Leitner, op. cit., s. 57.

43 B. Herrmann, Umweltgeschichte. Eine Einführung in Grundbegriffe, Heidelberg 2013, s. 8.

44 Alpenschutz-Transiterklärung, [w:] Im Tal: Asphalt und Betonbänder. Am Berg: Stacheldraht ums Edelweiß, „Tatort Brenner” 3, Transitforum Austria-Tirol, Innsbruck 2002, s. 14.

45 U. Jureit, Das Ordnen von Räumen. Territorien und Lebensraum im 19. und 20. Jahrhundert, Hamburg 2012, s. 12.

46 B. Tschofen, Was ist Landschaft? Plädoyer für Konzepte jenseits der Anschauung, [w:] Entdeckungen der Landschaft. Raum und Kultur in Geschichte und Gegenwart, red. M. Kasper et al., Wien-Köln-Weimar 2017, s. 13-32, tutaj s. 15.

47 W sumie sześć aspektów krajobrazu: cielesny i zmysłowy, estetyczny, tu istotny identyfikacyjny, polityczny, ekonomiczny i ekologiczny; N. Backhaus, C. Reichler, M. Stremlow, Ein Landschaftsmodell für den Alpenraum, Ein Landschaftsmodell für den Alpenraum — Erkenntnisse aus einem schweizerischen Forschungsprogramm, „Histoire des Alpes — Storia delle Alpi — Geschichte der Alpen” 12, 2007, s. 316. 
wających krajobraz alpejski jako codzienne środowisko, można mówić o takim poczuciu przynależności ${ }^{48}$. Choć Alpy odgrywały główną rolę w identyfikacji alpejskich obrońców środowiska, to do odgraniczenia, a tym samym do wzmocnienia tożsamości alpejskiej potrzebny był przeciwnik. Ze strony przeciwników ruchu tranzytu adwersarz taki został szybko znaleziony: Unia Europejska zlokalizowana w siedzibie w Brukseli. Alpejscy obrońcy środowiska nieustannie krytykowali Unię Europejską — jak twierdzi Andreas Weissen, były prezes CIPRA:

Polityka europejska jest mało przyjazna Alpom, zarówno w dziedzinie rolnictwa i zagospodarowania przestrzeni, jak i w całości. Jest w niewielkim stopniu dopasowana do potrzeb związanych z przestrzenią alpejską oraz nie bierze pod uwagę panujących tu szczególnych uwarunkowań ekologicznych i ekonomicznych ${ }^{49}$.

Tego rodzaju przykłady można by mnożyć. Tak jak to konstatował Romed Aschwanden w odniesieniu do Szwajcarii, alpejscy obrońcy środowiska postrzegali bogactwo przyrody i kultury Alp jako zagrożone przez Unię Europejską: z jednej strony ze względu na popierany i oczekiwany ruch tranzytowy, z drugiej zaś ze względu na koncentrację władzy politycznej w europejskim centrum rządzenia Brukseli ${ }^{50}$. Odnosi się to również do tyrolskich obrońców środowiska. Podobnie jak w Szwajcarii i Republice Alpejskiej w trakcie dyskusji o możliwościach wstąpienia Austrii do Unii Europejskiej w prasie i w dyskursie publicznym pojawiły się krytyczne wypowiedzi obrońców środowiska ${ }^{51}$.

$\mathrm{O}$ ile adresatem protestu była z początku polityka lokalna, względnie narodowa, o tyle zmieniło się to zwłaszcza w toku dyskusji o wstąpieniu Austrii do Unii Europejskiej, pod koniec lat osiemdziesiątych. Unia Europejska przystąpiła do gry i jako nowy gracz szybko stała się adresatem pretensji lokalnych działaczy przypisujących jej winę za wiele problemów powstałych na terenie Alp. Przez protestujących Unia Europejska była postrzegana nader ambiwalentnie: z jednej strony uważano ją za źródło wszelkiego zła - krytykowano wszak zasadę swobodnego przepływu towarów w ramach rynku unijnego, a także deficytowy z punktu widzenia alpejskich obrońców środowiska sposób myślenia skoncentrowany na gospodarce bez uwzględnienia komponentów ekologicznych. Z drugiej strony przeciwnicy ruchu tranzytowego mieli świadomość, że problemy związa-

48 Należy tu wskazać na konieczność analitycznego rozróżnienia między wyimaginowanym i rzeczywistym stosunkiem do krajobrazu; na płaszczyźnie dyskursywnej jednak rozróżnienie to nie odgrywa roli; por. J. Radkau, Germany as a Focus of European "Particularities" in Environmental History, [w:] Germany's Nature. Cultural Landscapes and Environmental History, red. T. Lekan, T. Zeller, New Brunswick 2005, s. 18.

49 A. Weissen, Eröffnung und Begrüßung, Tagungsband der CIPRA-Jahresfachtagung „Die Europäische Union und die Alpen” 25.10.2001, s. 13.

50 R. Aschwanden, op. cit., s. 259.

51 Por. F. Gurgiser, E. Lichtenberger, [w:] Europaforum - pro und contra EU-Beitritt, ORFSendung, 29.05.1994; J. Bertsch, Transitwiderstand in Tirol, [w:] Überrolltes Österreich. Zukunft unter dem Transitverkehr, red. H. Koch, H. Lindenbaum, Wien 1991, s. 167-178; H. Sickinger, R. Hussl, op. cit., s. 87.

Góry - Literatura - Kultura 14, 2020

(C) for this edition by CNS 
ne $\mathrm{z}$ transportem i środowiskiem mogą zostać rozwiązane tylko na płaszczyźnie europejskiej. Obok tej realnej politycznej płaszczyzny „Europa” tudzież „Unia Europejska" miały dla zaangażowanych postaci znaczenie jako punkt odniesienia w dyskusji. Protesty oznaczały nieustanne negocjowanie stanowiska alpejskich obrońców środowiska wobec Unii Europejskiej, a tym samym zabezpieczenie własnego stanowiska. Unia Europejska stała się przeciwnikiem, odnośnie do którego mierzono sukces i porażkę. Tym sposobem Unia, będąc adresatem protestów, wspierała kolektywną alpejską tożsamość, gdyż służyła alpejskim obroncom środowiska jako przeciwnik, dzięki któremu można było upewnić się we własnej tożsamości i odgraniczyć ją: Unia Europejska jako uosobienie interesów gospodarczych i Alpy jako przestrzeń wrażliwa ekologicznie, którą należy chronić. Nie należy jednak nadinterpretować krytyki płynącej ze strony alpejskich obrońców środowiska jako chęci całkowitego odrzucenia tej instytucji. Szczególnie Fritz Gurgiser wciąż to podkreślał. Jego krytyka odnosiła się wyłącznie do centralizmu i oderwania od obywateli:

Ta Europa daleka jest od unii, od wspólnoty. Dopiero gdy zostanie zrozumiane, że trzeba brać pod uwagę najróżniejsze uwarunkowania i topografie w krajach członkowskich, Europa stanie się rodziną, unią. Może się to stać tylko wtedy, kiedy Alpy upomną się o swoje prawa ${ }^{52}$.

\section{Podsumowanie}

Alpejscy obrońcy środowiska deklarowali, że Alpy są dobrem ogólnym, które — wedle ich rozumienia — potrzebuje zaangażowania zamieszkującej je ludności, aby chronić ten kruchy system ekologiczny przed zakusami z zewnątrz. Nakreślone tu przemyślenia ukazały możliwość scharakteryzowania alpejskich obrońców środowiska jako zarządców i spadkobierców przestrzeni alpejskiej. Szczególnie wyraźnie widać to w tak zwanym Brenner-Memorandum z roku 2006:

[Chcemy] dać naszym dzieciom pewność, że jesteśmy świadomi odpowiedzialności za naszą ojczyznę, jak i zobowiązania do zabezpieczenia podstaw życiowych i gospodarczych, tak aby nasze dzieci także mogły na tym terenie żyć, gospodarować, pracować i odpoczywać przez kolejnych 5, 10, 20 i 50 lat $^{53}$.

Także związki alpejskie widzą siebie jako „adwokatów alpejskiego krajobrazu naturalnego i kulturowego" ${ }^{54}$. Alpejscy obrońcy środowiska wygenerowali

52 F. Gurgiser, Widerstand gegen den Alpentransit - Mythos oder Überlebenskampf, [w:] Mythos Alpen. CIPRA Jahreskonferenz, 10.-12. Oktober 1996, Igls, red. Ch. Wildburger, Wien 1996, s. 101-104, tutaj s. 103.

53 Transitforum Austria-Tirol, Brenner Memorandum, Brennerpass (Tirol), 26.05.2006, http:// www.transitforum.at/pdf/20060602MemoGurgiser.pdf (dostęp: 28.08.2019).

${ }^{54}$ Helfen wir den Alpen, s. 3. 
różnorodne obrazy Alp oraz skonstruowali przestrzeń dyskursywną, która mogła być odgrywana wciąż na nowo i stanowiła płaszczyznę projekcyjną w zależności od kontekstu zapełnianą różnymi znaczeniami. Ochrona Alp wpisywała się tu w nowoczesną tradycję ochrony środowiska i przyrody: nie chodziło o funkcję zachowawczą, lecz o funkcję ochronną w kombinacji z rozwojem gospodarczym, społecznym i kulturalnym terenów alpejskich. Zdeklarowanym celem obrońców środowiska była ostatecznie ochrona środowiska idąca $\mathrm{w}$ parze $\mathrm{z}$ potrzebami ekologicznymi i społecznymi. W tym miejscu należy krytycznie zauważyć, że ten inspirowany ekologicznymi kryteriami sposób widzenia prezentowany przez alpejskich obrońców środowiska w Tyrolu był jednakowoż związany ze starą romantyczną tradycją widzenia Alp i zawierał konotacje moralne.

Konieczność ochrony Alp ponad granicami była rozumiana jako common sen$s e$. Możliwe to było tylko na tle integracji europejskiej. Tak więc Unia Europejska odgrywała dla tyrolskich obrońców Alp rolę punktu odniesienia w dyskusji istotną, a zarazem ambiwalentną: posłużyła za to, co „inne” w odróżnieniu od „własnego" - umiejscawiającego się w Alpach w odróżnieniu od abstrakcyjnej wielkości „Unia Europejska”. Alpejscy obrońcy środowiska z jednej strony stylizowali Alpy na służący w kontekście ekologicznym przykładem modelowy region w opozycji do nakierowania na wartości ekonomiczne Unii Europejskiej. Z drugiej strony Unia Europejska grała rolę wspólnego przeciwnika, co nie tylko sugerowało jedność obszaru Alp, lecz także uwypuklało ich rolę w dyskusji. Tak to Alpy zostały wprowadzone przez alpejskich obrońców środowiska jako argument na arenę polityczną. Alpejscy obrońcy środowiska uważali taką zamkniętą jedność za nieodzowną do przeforsowania własnych wewnątrz alpejskich potrzeb i interesów wobec poza alpejskich dotyczących wykorzystania $\mathrm{w}$ dziedzinie transportu.

Alpy posłużyły więc w równym stopniu za przestrzeń wyobrażeń, ramy odniesienia i punkt zapalny celem tematyzowania problemów ekologicznych. Reasumując, trzeba wskazać, że Alpy prezentowały się jako skonstruowana dyskursywnie przestrzeń, w której negocjowano różne, po części przeciwstawne, interesy ekonomiczne, ekologiczne i polityczne. Należy zaznaczyć, że działaniem alpejskich obrońców środowiska w Tyrolu Północnym i Południowym kierowała nałożona przez nich na siebie rola depozytariuszy, zarządców i adwokatów Alp. O ile w przedmodernistycznej europejskiej historii kultury Alpy jawiły się jako groźne, o tyle dla alpejskich obrońców środowiska sytuacja przedstawiała się odwrotnie - teraz to właśnie same Alpy były coraz bardziej zagrożone współczesnymi problemami środowiskowymi i to je należało chronić przed tymi zagrożeniami, tak aby zachować przestrzeń życiową i gospodarczą Alp dla siebie samych, ich mieszkańców.

Zjęzyka niemieckiego przełożyła Monika Witt 